\title{
Removal of Lead (II) of waters from Anticona Cerro de Pasco River (Perú) through the use of orange
} mesocarpactivated carbon (Citrus sinensis)

\author{
Candelaria Tejada-Tovar ${ }^{\sharp 1}$, Dax Humberto Bonilla-Mancilla ${ }^{* 2}$, Yenny Del Pino-Moreyra ${ }^{\$ 3}$, \\ Angel Villabona-Ortiz ${ }^{\sharp 4}$, Diofanor Acevedo ${ }^{85}$ \\ \# Faculty of Engineering, Chemical Engineering program, University of Cartagena, Av. El Consulado, \\ St. 30 No. 48-152. Cartagena de Indias, Colombia. \\ * Faculty of Forestry and EnvironmentalSciences, Universidad Nacional del Centro del Perú, \\ El Tambo Huancayo, Perú. \\ ${ }^{\$}$ Faculty of Nursing, National University of the Center of Peru, El Tambo Huancayo, Peru. \\ ${ }^{\&}$ Faculty of Engineering, Food Engineering program, Research Group NUSCA, University of Cartagena \\ Av. El Consulado, St. 30 No. 48-152. Cartagena de Indias, Colombia \\ ${ }^{1}$ ctejadat@unicartagena.edu.co, ${ }^{2}$ daxbeto@hotmail.com, ${ }^{3}$ jenny_dpm@hotmail.com, \\ 4avillabonao@unicartagena.edu.co, ${ }^{5}$ diofanor3000@gmail.com
}

\begin{abstract}
The objective of this study was to evaluate the use of activated carbon obtained from orange peel (Citrus sinensis) in the removal of $\mathrm{Pb}$ (II) ions present in the waters of the Anticona-Cerro de Pasco River.Activated carbon with phosphoric acid was prepared as an activating agent in an impregnation ratio of $0.70 \mathrm{~g} \mathrm{H}_{3} \mathrm{PO}_{4}$ per gram of material.The physicochemical properties of the adsorbent were studied using the isothermal adsorption of nitrogen (BET), electron microscopy (SEM) and infrared spectrophotometry with Fourier transform (FTIR).The most influential factors in the adsorption process were the $\mathrm{pH}$ of the solution, contact time, porous structure and acidity of the carbon.The results indicate that Freundlich's model is the one that best adjusts the experimental data, reaching a bioadsorption capacity of $478.5 \mathrm{mgL}^{-1} \mathrm{~Pb}$ (II), which represents $95.70 \%$ lead removal (II).
\end{abstract}

Keyword - Adsorption, bio-carbon, Freundlich's isothermal.

\section{INTRODUCTION}

Contamination of drinking water sources by pathogens, toxic inorganic organisms, radionuclides and synthetic and emerging organic pollutants is a public health concern; the presence of heavy metals being one of the greatest, due to inadequate treatment of wastewater discharged into water bodies and containing heavy metals such as lead, chromium, cadmium, cobalt and zinc, which are toxic to living organisms and which due to their physicochemical properties are not biodegradable [1]-[3].

In this context, the exploitation of mineral resources has been considered an essential activity for the development of countries such as Peru, highlighting the production of lead, which has increased over the years, consolidating itself as one of the most important producers of lead in the world [4]. However, it has brought with it a series of negative effects on the environment, causing profound changes, with the consequent deterioration of landscapes, plants, water [5].

The central region of Peru is among the most affected with this environmental problem, the presence of lead in the upper zone (Cerro de Pasco) and average of the Mantaro River basin is variable, evidenced in the source of the Mantaro River values that exceed the LBC-PMR $=0.0210 \mathrm{mg} \mathrm{L}^{-1}$, being the stations of greatest concern San Juan $=0.049 \mathrm{mg} \mathrm{L}^{-1}$, Anticona River $=0.630 \mathrm{mg} \mathrm{L}^{-1}$, before discharge to Mantaro, where it exceeds between 2.3 and 30 times respectively the LBC-PMR, and 196.9 and 15.3 times the standard proposed by CONAMA-Chile class a1 $\left(0.0032 \mathrm{mg} \mathrm{L}^{-1}\right)$ respectively.It is important to note that the concentration of lead in the Anticona River exceeds 6.3 times the class III standard of the General Water Law-LGA [6].

Thus, a variety of technologies have been adopted for the removal of heavy metals in wastewater, such as chemical oxidation, precipitation, adsorption, ion exchange, reverse osmosis and membrane separation.Adsorption is the process in which molecules are concentrated in an interfacial layer and are considered an effective remediation strategy due to the low cost and regeneration of adsorbent, high selectivity, and simple design [7].

The adsorption process uses various organic and inorganic materials as adsorbents that can be of natural or synthetic origin, the selection of an adsorbent material is based on structural, chemical, surface and morphological characteristics.Different residual biomasses have been used for the removal of lead in solution, 
including corn husks and orange peels [8], Fumariaindica[9], aquatic mosses [10], peanut shells [11], walnut shells [12], among others. There has also been interest in obtaining porous materials with good physico-chemical properties, such as activated carbon, to be applied in the field of contaminant removal technology in aqueous media [13].

Many of these coals are obtained from agricultural or industrial waste, which reduces the cost of these, and also generates alternatives for waste treatment, among the precursors used include nut shells [14], sesame seeds [15], cane (Phragmitesaustralis) [16], olive and cherry seeds [17], coconut shells [18], among others. In this way, in the present research, the use of orange peels was experimented as a precursor for the production of phosphoric acid impregnated activated carbon (H3PO4) in the adsorption of $\mathrm{Pb}$ (II) present in the waters of the Anticona River.

\section{A. Area of study and sampling sites}

The Anticona River is located between the Vicco and Huayllay districts, in the Cerro de Pasco region of Peru, where effluents from the Pan American Silver mine operating through CompañíaMineraHuarón are the main pollutants of $\mathrm{Pb}$ (II) waters. Sampling of waters was carried out according to the protocols proposed by DIGESA with Directoral Resolution No. 2254/2007/DIGESA/SA [6]. Four sampling points were chosen, depending on the review of existing information, population interviews and field visits (Fig. 1).

Punctual sampling was carried out, which consisted of taking the samples at the point fixed at the date and time established. Composite sampling was also done, which consisted of obtaining several samples during an eight-hour period at the same sampling point, these samples were taken every hour and then homogenized to obtain a representative sample of $5 \mathrm{~L}$ of water.
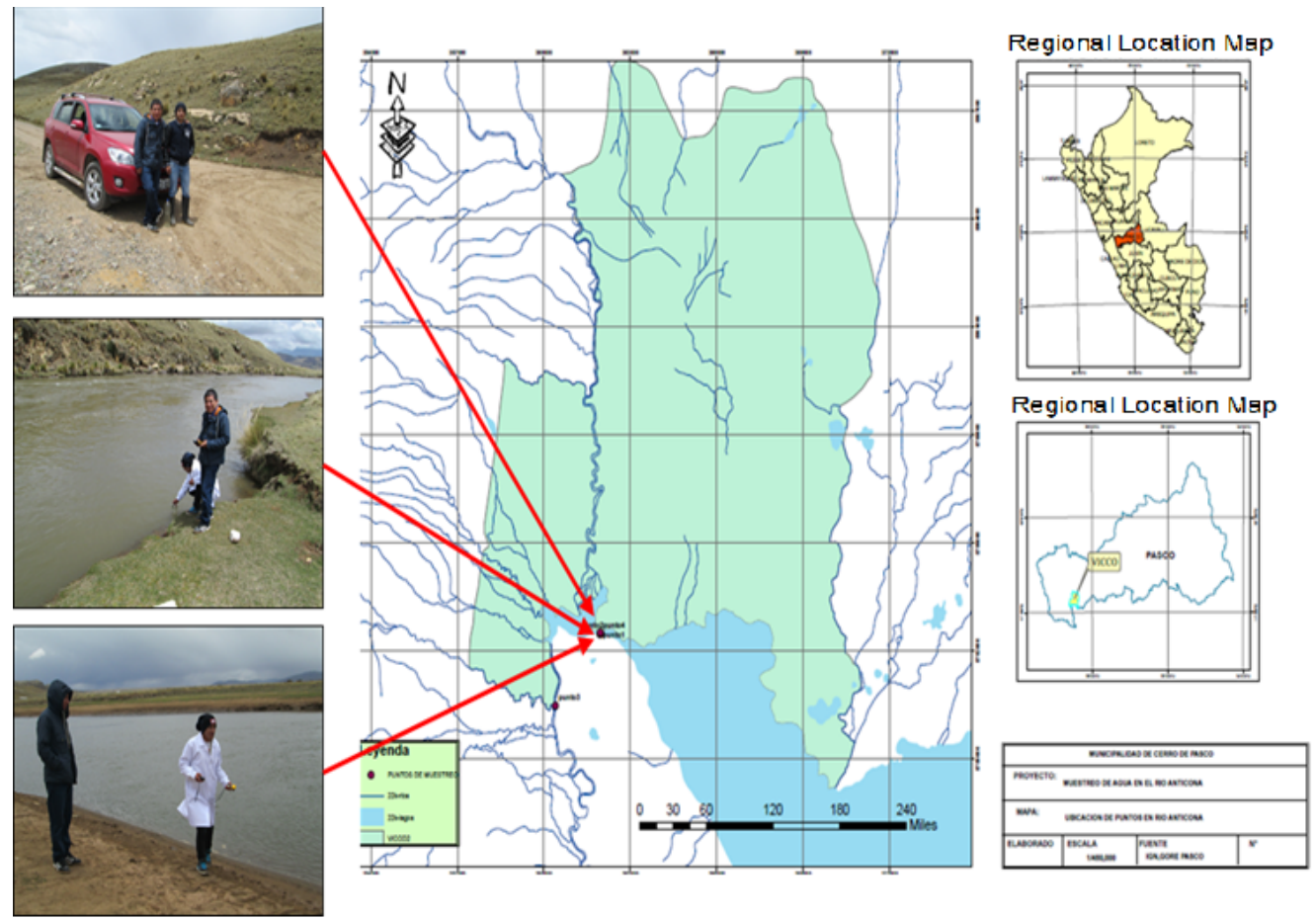

Fig. 1. Sampling points on the Anticona - Cerro de Pasco River.

\section{B. Pre-treatment and characterisation of the activated carbon precursor}

The orange peel (Citrus sinensis), from the central jungle of Peru, was prepared to obtain activated carbon by the following procedure: reduction of size in pieces of approximately 5-7 mm and heating in muffle at $700^{\circ} \mathrm{C}$ for $1 \mathrm{~h}$, to be dried in a desiccator.Afterwards, $5 \mathrm{~g}$ of raw material (M1) was weighed, heated to $110^{\circ} \mathrm{C}$ for 1 hour, then placed in the desiccator until it cooled down and then weighed (M2). The dry samples were then placed in the oven at $700{ }^{\circ} \mathrm{C}$, one sample was left for $15 \mathrm{~min}$ to determine its dry weight and the amount of volatile material (M3) and the other for $1 \mathrm{~h}$, to determine the ash content (M4), the percentages of moisture, volatile material and ash were determined with the following Equations 1 to 4 :

$\%$ Moisture $=\left(\frac{M_{1}-M_{2}}{M_{1}}\right) * 100$
$\%$ Volatile $=\left(\frac{M_{2}-M_{3}}{M_{1}}\right) * 100$ 
$\%$ Ash $=\left(\frac{M_{4}}{M_{1}}\right) * 100$

$\%$ Moisture $+\%$ Volatile material $+\%$ Ash $+\%$ Fixed carbon $=100 \%$

\section{Preparation of activated carbon}

The process of obtaining activated carbon was carried out by the following procedure: I) Impregnation of 50 $\mathrm{g}$ of orange peel (precursor) with $250 \mathrm{~mL}$ of $\mathrm{H} 3 \mathrm{PO} 4$ solution ( $85 \%$ purity), with a ratio of $0.70 \mathrm{~g} \mathrm{H} 3 \mathrm{PO} 4$ per $\mathrm{g}$ of precursor with constant agitation at $50{ }^{\circ} \mathrm{C}$ for $3 \mathrm{~h}$, followed by drying at $70{ }^{\circ} \mathrm{C}$ for 12 hours. II), Thermal activation of $50 \mathrm{~g}$ of impregnated and dry precursor in a muffle with heating rate of $7{ }^{\circ} \mathrm{C} / \mathrm{min}$, with continuous flow of $100 \mathrm{~mL}$ of $\mathrm{N}_{2} \mathrm{~min}^{-1}$ to reach the activation temperatures of 400,500 and $600^{\circ} \mathrm{C}$, respectively, during $1 \mathrm{~h}$. III). The activated carbons were initially washed with a $5 \% \mathrm{NaHCO}_{3}$ solution and then with plenty of distilled water to remove excess $\mathrm{H}_{3} \mathrm{PO}_{4}$. The activated carbons were then dried in a stove at $70^{\circ} \mathrm{C}$ for $10 \mathrm{~h}$.

\section{Characterization of coal and precursor}

Precursor and prepared coals were characterized by analytical tests: Fourier Transform Infrared Spectroscopy (FTIR), Scanning Electron Microscopy (SEM) and Brunauer-Emmett-Teller (BET) analysis, in order to know the structure of the material and the possible interactions of the ions with the material studied, its chemical composition on the surface and its apparent surface areas, respectively. The surface chemistry and determination of the functional groups of the precursor was performed by FTIR analysis using a Shimadzu FTIR-8700 infrared spectrophotometer. The samples were dried in an oven for $15 \mathrm{~h}$ at a temperature of $100^{\circ} \mathrm{C}$. Then they were pulverized and homogenized in a mortar.A scanning electron microscope model EVO $10 \mathrm{Z} 6$ was used for the SEM analysis of the carbons and precursor. Powdered and low vacuum (20 torr) and $\mathrm{N}_{2}$ samples were used as $99.99 \%$ purity adsorbate for the structural characterization of coal, with tests carried out at $77 \mathrm{~K}$ in the relative pressure range of 0.005 to 1 using Gemini VII model 23901. The isothermal graph was linearized according to the BET model.

\section{E. Determination of operating conditions}

The conditions under which the adsorption tests were carried out were determined: to establish the contact time, a $100 \mathrm{mg} \mathrm{L}^{-1}$ solution of $\mathrm{Pb}$ (II) was prepared, using lead nitrate for the preparation of the standard solution; it was placed in contact at different intervals of time $(0 \leq \mathrm{t} \leq 5 \mathrm{~h})$ at room temperature with $20 \mathrm{mg}$ activated carbon with $\mathrm{H} 3 \mathrm{PO} 4$ at $150 \mathrm{rpm}$; the solution was then filtered and the residual lead concentration in the solution was determined.The effect of $\mathrm{pH}$ at different values (2 to 7) was studied, keeping it constant for each test, adjusting it with $\mathrm{NaOH}$ and $\mathrm{HCl} 0.1 \mathrm{M}$. For 60 min the same amount of adsorbent with a $100 \mathrm{mg} \mathrm{L}^{-1}$ solution of contaminant at $150 \mathrm{rpm}$ was placed.To establish the activation temperature, heat treatment was carried out by heating the activated carbons with $\mathrm{H}_{3} \mathrm{PO}_{4}$ in a muffle with a heating ramp of $7{ }^{\circ} \mathrm{C} \mathrm{min}^{-1}$, with a continuous flow of $100 \mathrm{~mL}$ of $\mathrm{N}_{2} \mathrm{~min}^{-1}$ in a range of 400 to $600{ }^{\circ} \mathrm{C}$ and the residual concentration in the solution was determined.

\section{F. Determination of adsorbent effectiveness}

In order to determine the effect of activated carbon quantity with $\mathrm{H}_{3} \mathrm{PO}_{4}$ on $\mathrm{Pb}$ (II) adsorption, the conditions shown in Table 1 were studied.

Table 1. Mass of activated carbon with phosphoric acid

\begin{tabular}{cc}
\hline Treatments & Adsorbent mass (mg) \\
\hline T1 & 2 \\
T2 & 5 \\
T3 & 10 \\
T4 & 15 \\
T5 & 20 \\
\hline
\end{tabular}

\section{G. Kinetic and isothermal modeling}

The adsorption kinetics were determined by contacting $100 \mathrm{~mL}$ of water from the Anticona-Cerro de Pasco River with $20 \mathrm{mg}$ of activated carbon at $120 \mathrm{rpm}$ with $\mathrm{H}_{3} \mathrm{PO}_{4}$, taking as independent variables the $\mathrm{pH}$ (3-5), during $120 \mathrm{~min}$, following a factorial design $2^{2}$, and fitting the experimental data to pseudo-primer order, pseudo-second order, Elovichand intraparticular diffusion.

To adjust the data to the Langmuir and Freundlich isotherms, five aqueous solutions were placed in contact at concentrations of $20 \mathrm{mgL}^{-1}, 16 \mathrm{mg} \mathrm{L}^{-1}, 12 \mathrm{mg} \mathrm{L}^{-1}, 8 \mathrm{mg} \mathrm{L}^{-1}$ and $4 \mathrm{mg} \mathrm{L}^{-1} \mathrm{~Pb}$ (II) at $20 \mathrm{~g}$ adsorbent, a volume of $50 \mathrm{~mL}, \mathrm{pH} 5$, at a constant temperature for $60 \mathrm{~min}$. 
The adsorption capacity was determined based on the principle of mass transfer according to equation 5 : where $\mathrm{Ci}$ and $\mathrm{Ce}$ are the initial and final concentration of lead (II) in the solution, respectively in $\mathrm{mg} \mathrm{L}^{-1}$. $\mathrm{V}^{\text {the }}$ volume of the solution in $\mathrm{L}$ and $\mathrm{m}$ the mass of adsorbent in $\mathrm{g}$.

$$
q_{e}\left[\frac{m g}{g}\right]=\frac{\left(C_{i}-C_{e}\right) V}{m}
$$

\section{III.RESULTS AND DISCUSSIONS}

\section{A. Proximal chemical analysis of the precursor}

As shown in Table 2, the precursor shows a fixed coal content $(10.832 \%)$ and a low ash value $(0.398 \%)$; suitable characteristics in the biological material to be transformed into activated carbon. The decrease in humidity and increase in ash and fixed carbon when the precursor is impregnated with phosphoric acid, could be due to the dehydrating characteristics of $\mathrm{H}_{3} \mathrm{PO}_{4}$, which facilitates the loss of hydrogen and oxygen in the form of water, a process that occurs simultaneously with the compaction of large carbon units to smaller units and enriched in coal [19].

Table 2. Chemical - proximal analysis of precursor and activated carbon with $\mathrm{H}_{3} \mathrm{PO}_{4}$.

\begin{tabular}{ccccc}
\hline Sample & Moisture (\%) w w $\mathbf{w}^{-\mathbf{1}}$ & Volatile (\%) w w $\mathbf{w}^{-\mathbf{1}}$ & Ash (\%) w w $^{-\mathbf{1}}$ & Fixed coal (\%) w w $^{-\mathbf{1}}$ \\
\hline \multirow{2}{*}{ PrecursorCA with } & 5.62 & 83.15 & 0.398 & 10.832 \\
$\mathrm{H}_{3} \mathrm{PO}_{4}$ & 4.52 & 29.32 & 13.05 & 58.71 \\
\hline
\end{tabular}

The results obtained in the present study are similar to those reported by Borghi [20], whose proximal chemical analysis of banana peel is: humidity $5.12 \%$; ash $0.51 \%$; coal $9.65 \%$; volatile material $80.24 \%$.

\section{B. FTIR Analysis}

The FTIR analysis allowed to know the surface chemistry of activated carbon without phosphoric acid and activated carbon with $\mathrm{H} 3 \mathrm{PO} 4$, obtaining information from the functional groups present on the surface of activated carbon, which are decisive in the bioadsorption process, which are shown in Table 3:

Table 3. FTIR analysis of activated carbons from orange peel.

\begin{tabular}{|c|c|c|c|}
\hline \multicolumn{2}{|c|}{$\mathrm{CA} \sin \mathrm{H}_{3} \mathrm{PO}_{4}$} & \multicolumn{2}{|c|}{$\mathrm{CA} \operatorname{con} \mathrm{H}_{3} \mathrm{PO}_{4}$} \\
\hline $\begin{array}{l}\text { Adsorption } \\
\text { peak }\left(\mathrm{cm}^{-1}\right)\end{array}$ & Group & Adsorption peak $\left(\mathrm{cm}^{-1}\right)$ & Grupo \\
\hline 2297 & Alkanes Stretching $(\mathrm{CH})$ & 3732 & $\mathrm{OH}$ group vibration \\
\hline 2869 & Alkyl groups & 2859 & Alkanes and alkyl $(\mathrm{C}-\mathrm{H})$ tension \\
\hline 1703 & $\begin{array}{l}\text { Group } \mathrm{C}=\mathrm{O} \text { of esters, } \\
\text { aldehydes and lactone }\end{array}$ & 2353 & $\mathrm{C} \equiv \mathrm{C}$ Tension \\
\hline 1580.3 & Stretching of $\mathrm{C}=\mathrm{C}$ & 1732 & $\begin{array}{l}\text { Vibration of the carboxyl group of } \\
\text { aldehydes, ketones and carboxylic } \\
\text { acids }\end{array}$ \\
\hline 1580 & $\mathrm{C}-\mathrm{C}$ & 1413,7 & $\begin{array}{l}\text { Bending in the plane of aliphatic } \\
\text { groups }\left(\mathrm{CH}_{3} \text { and } \mathrm{CH}_{2}\right)\end{array}$ \\
\hline 1321 & $\begin{array}{l}\text { Bending in the } \mathrm{C}-\mathrm{O} \text { link } \\
\text { plane }\end{array}$ & 972,1 & Alkenes vibrations C-H \\
\hline 1076,2 & Groups $\mathrm{CH}_{3}$ and $\mathrm{CH}_{2}$ & 2927.9 & $\mathrm{CH}$ Group of the $\mathrm{H}_{3} \mathrm{PO}_{4}$ \\
\hline
\end{tabular}

From the reported peaks it is established that functional groups undergo various chemical changes during pyrolysis, caused by the influence of the activating agent, with respect to the functional groups of activated carbon without phosphoric acid. Thus, the signs are observed around 2927,9 and $3732 \mathrm{~cm}^{-1}$ corresponding to group $\mathrm{C}-\mathrm{H}$ and group $\mathrm{O}-\mathrm{H}$ (alcohols and phenols), respectively.This marked difference is due to the action of $\mathrm{H}_{3} \mathrm{PO}_{4}$ on the precursor, constituting the appearance of the band around $3732 \mathrm{~cm}^{-1}$ assigned to groups $\mathrm{P}=\mathrm{O}$ of phosphates or polyphosphates, which together with the phenol $\mathrm{O}-\mathrm{H}$, are acid groups.

The stretching of the alkanes and $\mathrm{OH}$ groups indicates that phosphoric acid acted as a dehydrating agent and eliminated a considerable amount of hydrogen from the precursor; on the other hand, the stretching of alcohols, carboxylic acids, esters and ethers, are related to the removal of hydrogen and oxygen [21], [22]. 


\section{Morphological analysis of carbons by SEM}

Microphotographs of carbon without phosphoric acid and activated carbon with H3PO4, obtained by SEM analysis are shown in Fig. 2 and 3. The H3PO4 activated carbon samples in Fig. 3 present heterogeneous porous structures, with predominance of large pores and agglomerates.In contrast, the samples without $\mathrm{H}_{3} \mathrm{PO}_{4}$ in Fig. 2 have a compact structure but with more homogeneous porosity with predominance of small pores (micropores). This result confirms that carbon activation with $\mathrm{H}_{3} \mathrm{PO}_{4}$ and activation temperature cause an increase in the degree of activation, reflected in a higher microporosity of the material [23].

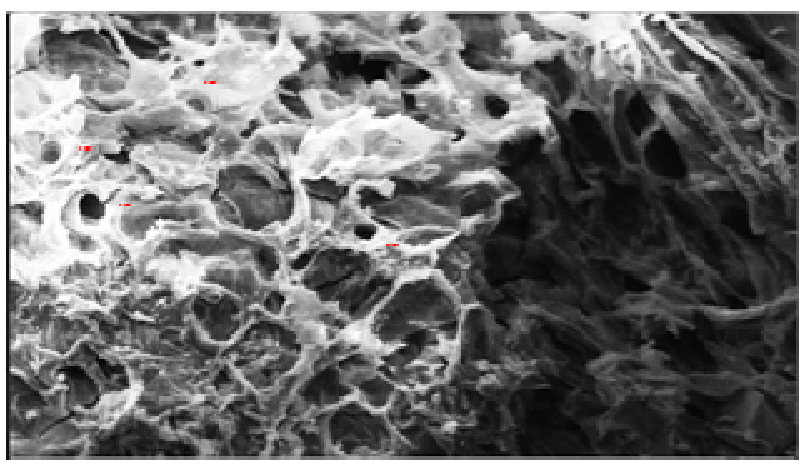

(a)



(b)

Fig. 2. Porosity microphotograph of orange peel $\mathrm{AC}$ with $\mathrm{H}_{3} \mathrm{PO}_{4}$, (a) Magnification x1000; (b) Magnification $\mathrm{x} 100$

Nayaket al.[24] found that after the activation of sawdust, well-developed pores and cavities were obtained, which are absent in the precursor before activation, causing chemical activation along with carbonization and a change in the morphology of activated carbons. This effect is confirmed by the results obtained in this research, representing a very porous structure, and confirms the effect of the activating agent with respect to activated carbon without phosphoric acid.

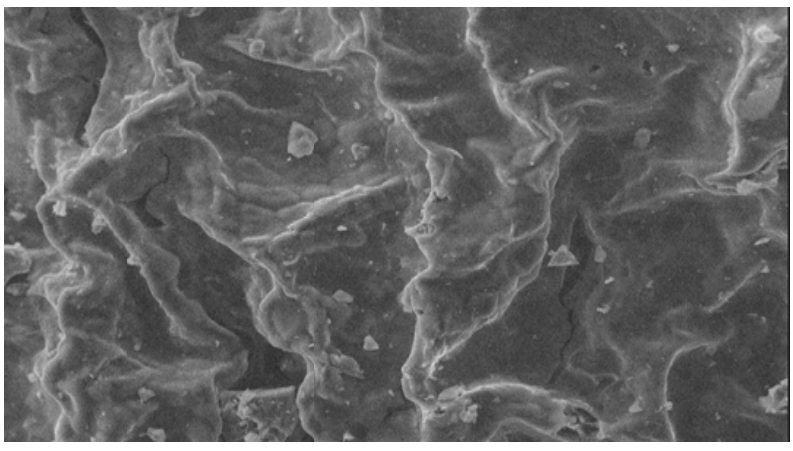

(a)

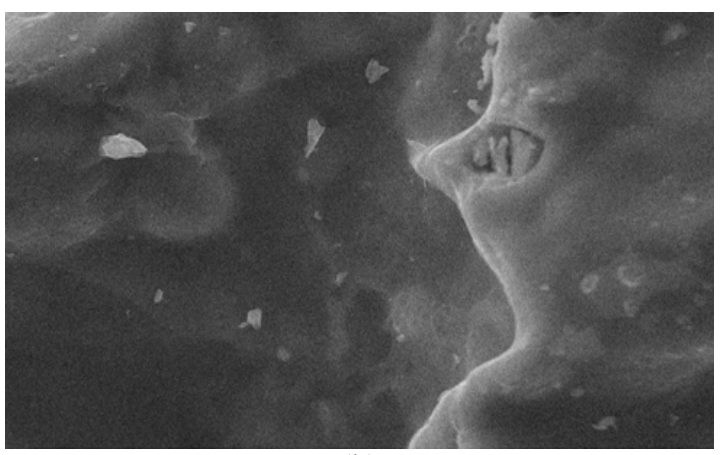

(b)

Fig. 3. Micro-photography of porosity of unactivated orange peel activated carbon. (a) Magnification x100, (b) Magnification x 500

\section{BET Analysis}

After applying the BET method, the adsorption isotherm was obtained for biomass, as shown in Fig. 4. A surface area of activated carbon with H3PO4 of $1626.44 \mathrm{~m} 2 / \mathrm{g}$ and activated carbon without phosphoric acid of $33.537 \mathrm{~m}^{2} \mathrm{~g}^{-1}$ was obtained; this increase in surface area shows that phosphoric acid penetrated the surface of the material. 


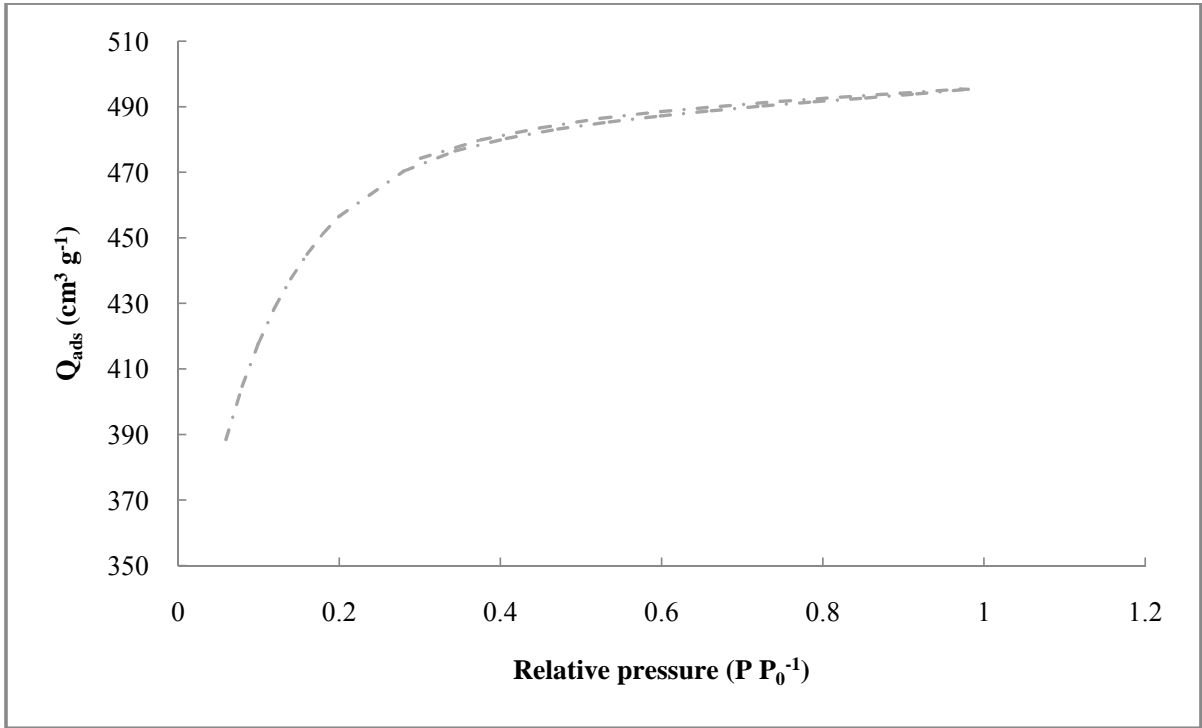

Fig. 4. Adsorption isotherm of nitrogen per gram of activated carbon with $\mathrm{H}_{3} \mathrm{PO}_{4}$ in relation to the adsorbed volume of $\mathrm{N}_{2}\left(\mathrm{~cm}^{3} \mathrm{~g}^{-1}\right)$ under normal conditions.

The nitrogen adsorption/desorption curve describes a type IV curve according to IUPAC, which represents the adsorption isotherm with hysteresis associated mainly with mesopores in activated carbon [25].The literature has reported activated carbons with areas of $1974 \mathrm{~m}^{2} \mathrm{~g}^{-1}$ modified with $\mathrm{H} 3 \mathrm{PO} 4$ at $30 \%$, and $794 \mathrm{~m}^{2} \mathrm{~g}-{ }^{1}$ chemically modified with $\mathrm{ZnCl}_{2}$ and carbonized at temperatures above $500{ }^{\circ} \mathrm{C}$, which gives an acceptable range for the surface area of activated carbon area values synthesized in this study [23].

\section{E. Determining the operating conditions}

Contact kinetics is an important variable in adsorption, since it measures the saturation time of active adsorbent sites and helps to define adsorption velocity. The results of experiments to determine equilibrium time are shown in Fig. 5a, showing that removal of $\mathrm{Pb}$ (II) was initially rapid, reaches equilibrium in $95 \mathrm{~min}$ and continues to increase, which can be caused by initial saturation of active sites by mass transfer [13].



(a)

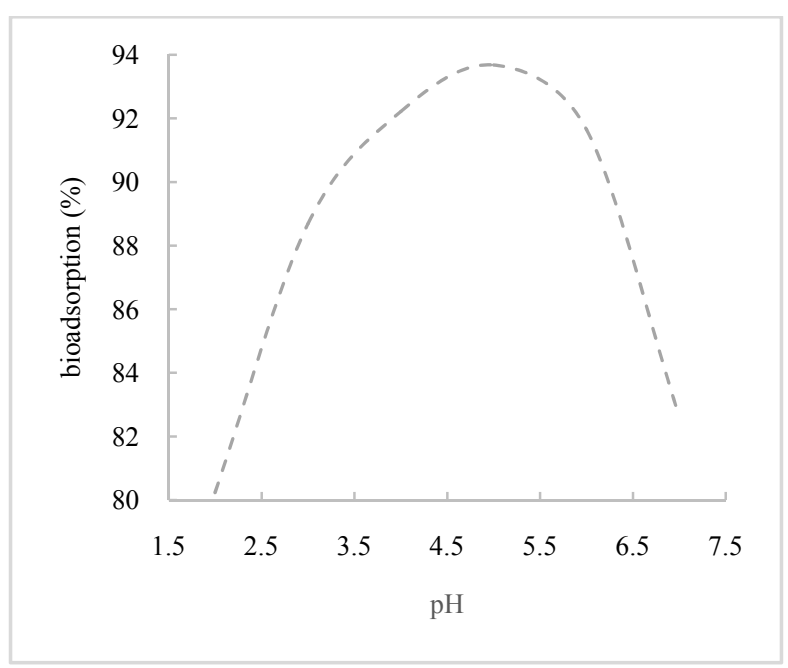

(b) 


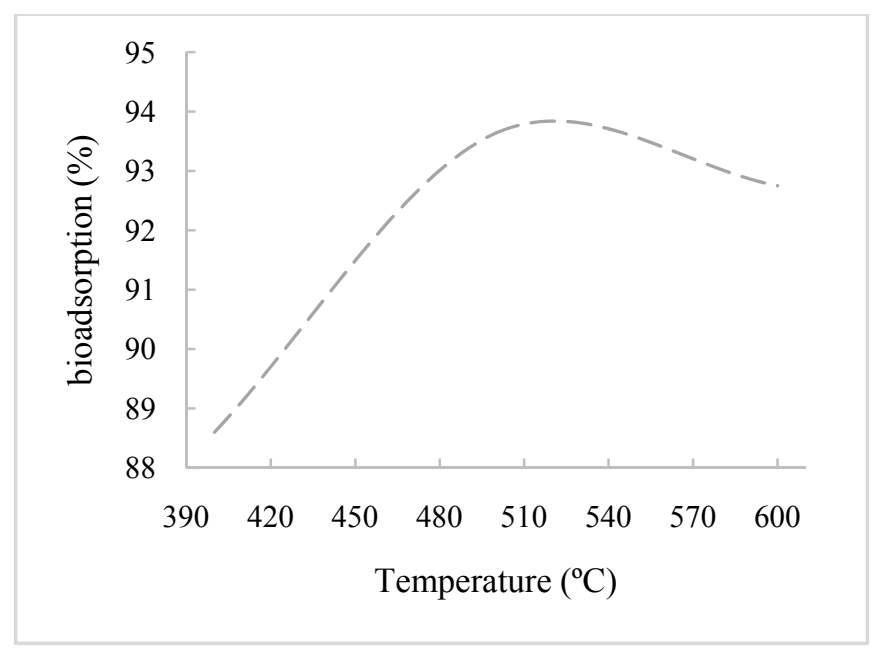

(c)

Fig. 1. Effect of contact time (a), effect of $\mathrm{pH}(\mathrm{b})$, effect of activation temperature (c) on the removal of $\mathrm{Pb}$ (II) using activated carbons with $\mathrm{H}_{3} \mathrm{PO}_{4}$

The effect of $\mathrm{pH}$ on adsorption is important because it is associated with the surface nature of activated carbon and the predominant species of adsorbate, it is observed in Fig. $2 b$ that the highest percentage of adsorption was achieved at $\mathrm{pH} 5$, which is due to the fact that high $\mathrm{pH}$ increases the concentration of $\mathrm{OH}$ anions,inducing changes in the surface of the adsorbent and increasing the adsorption of metallic ions such as lead, since in solution its predominant species are cations of $\mathrm{Pb}(\mathrm{OH})_{2}$ and $\mathrm{PbCl}_{2}$, therefore there will be an electrostatic attraction with $\mathrm{OH}$ anions [26], [27].

Fig. 2c shows the percentage of $\mathrm{Pb}$ (II) adsorption at different carbon activation temperatures, showing that at $500{ }^{\circ} \mathrm{C}$ a higher percentage of adsorption was obtained, similar to that reported by Kyzaset al.[22], [28] and Abbas et al., [29]. The efficiency (\%) of impregnated and unimpregnated activated carbons with H3PO4 at the different activation temperatures was determined using the Equation 6, where WCA is the mass of activated charcoal and $\mathrm{Wp}$ is the mass of the precursor in $\mathrm{g}$, such results are shown in Table 3.

$$
n(\%)=\left(\frac{W_{C A}}{W_{P}}\right) * 100
$$

It is observed that the higher the activation temperature, the lower the yields, this calculated parameter is very similar to the revised literature.Delgadillo [30], mentions that the activated carbon of medlar seed with $\mathrm{H}_{3} \mathrm{PO}_{4}$ and subjected to the activation temperatures of $400^{\circ} \mathrm{C}$ and $500^{\circ} \mathrm{C}$ obtained a yield of $50.6 \%$ and $53.2 \%$ respectively, and the activated with $\mathrm{KOH}$ at $600^{\circ} \mathrm{C}$ a yield of $24.5 \%$.

Garcés and Coavas[31], report that the yield of activated carbon orange peel with chitosane is $41.4 \%$. Paredes [32], mentions that the yields of chestnut activated carbon with $\mathrm{H}_{3} \mathrm{PO}_{4}$ at temperatures of $400^{\circ} \mathrm{C}, 500^{\circ} \mathrm{C}$ and $600^{\circ} \mathrm{C}$ are $32.98 \%, 39.18 \%$ and $41.23 \%$ respectively. The effect of the activating agent with respect to the activation temperature is very important, in this respect Lavadoet al.[33] and Sun-Kou et al., [34] state that $\mathrm{H}_{3} \mathrm{PO}_{4}$ comes into contact with the precursor hydrolyzing the glycosidic bonds of biopolymers, accelerating the dehydration of the material at temperatures below $100{ }^{\circ} \mathrm{C}$.Thus, an increased relationship with this agent produces a more drastic attack on the structure, which is reflected in a decrease in performance.Precursor dehydration caused by $\mathrm{H}_{3} \mathrm{PO}_{4}$ is intensified with temperature increase, indicating that dehydration depends on temperature, due to the high packing density of the precursor resulting in reduced yield.

\section{F. Activated carbon efficiency in adsorption}

To calculate the effectiveness of adsorbent, a randomized design with five treatment units and five replicates was applied, using different adsorbent masses for $60 \mathrm{~min}$, determining the residual concentration $(\mathrm{Ce})$ in $\mathrm{mg} \mathrm{L}^{-1}$ of $\mathrm{Pb}$ (II) in solution as shown in Table 4.It was found that as the mass of activated carbon (mg) increases the adsorption efficiency (\%), so at a weight of $20 \mathrm{mg} \mathrm{AC}$ there is an efficiency of $95.686 \%$. 
Table 4. Effectiveness of adsorbent at different weights and percentage of bioadsorption of $\mathrm{Pb}$ (II)

\begin{tabular}{cccccccc}
\hline CA & Ce & Ce & Ce & Ce & Ce & Ce & Adsorptión (\%) \\
\hline 2 & 10 & 9.212 & 9.402 & 9.363 & 9.110 & 9.032 & 7.762 \\
\hline 5 & 10 & 8.103 & 8.321 & 8.034 & 8.121 & 8.100 & 18.642 \\
\hline 10 & 10 & 6.230 & 6.181 & 6.116 & 6.260 & 6.291 & 37.844 \\
\hline 15 & 10 & 1.361 & 1.561 & 1.262 & 1.271 & 1.365 & 86.360 \\
\hline 20 & 10 & 0.412 & 0.469 & 0.453 & 0.402 & 0.421 & 95.686 \\
\hline
\end{tabular}

\section{G. Adsorption tests of the Anticona-Cerro de Pasco River waters}

Table 5 shows the percentage of $\mathrm{Pb}$ (II) adsorption in the waters of the AnticonaRiver, whose initial concentration was $0.735 \mathrm{mg} \mathrm{L}^{-1} \mathrm{~Pb}$ (II), after the adsorption process the lead content was reduced by 0.2354 $\mathrm{mgL}^{-1}$, representing $67.97 \%$ of effectiveness, which translates into a maximum adsorption capacity of $25.4 \mathrm{mg}$ $\mathrm{g}^{-1}$.

Table 5. Bioadsorption of the $\mathrm{Pb}$ (II) of the waters of the Anticona River in percentage

\begin{tabular}{ccccc}
\hline $\mathbf{p H}$ & time (min) & $\mathbf{C o}\left(\mathbf{m g ~ L}^{-\mathbf{1}}\right)$ & ${\text { Ce } \mathbf{~ m g ~ L ~}^{-\mathbf{1}}}$ & Bioadsorption (\%) \\
\hline 5 & 60 & 0.735 & 0.2354 & 67.97 \\
& 120 & 0.735 & 0.2888 & 60.71 \\
3 & 60 & 0.735 & 0.3402 & 53.71 \\
& 120 & 0.735 & 0.4226 & 42.50 \\
\hline
\end{tabular}

It is observed that by lowering the $\mathrm{pH}$ and increasing the contact time, the adsorption capacity of $\mathrm{Pb}$ (II) decreases, which can be explained due to the low solubility of the metal, its high degree of self-complexity which is related to the interaction between the metal and the functional groups of the carbon surface [34].

\section{H. Kinetics and bioadsorption balance}

Adsorption kinetics describes the speed at which the adsorption is trapped. Their residence time in the solidssolution interface depends on this speed, allowing prediction of contaminant removal velocity (Tejada-Tovar et al. 2016). The adsorption kinetics of $\mathrm{Pb}$ (II) on activated carbon with $\mathrm{H}_{3} \mathrm{PO}_{4}$ corresponds to the experimental data in Fig. 6; according to the graph the ion adsorption was initially fast up to $20 \mathrm{~min}$, then it became slower and the equilibrium was reached about 70 min., achieving a maximum adsorption capacity of $478.5 \mathrm{mg} \mathrm{L}^{-1} \mathrm{~Pb}$ (II).The study of adsorption kinetics was carried out by applying pseudo-primer order, pseudo-second order, Elovich and intraparticular diffusion models, which were developed using Microsoft Excel's Solver tool, as shown in Fig. 6.

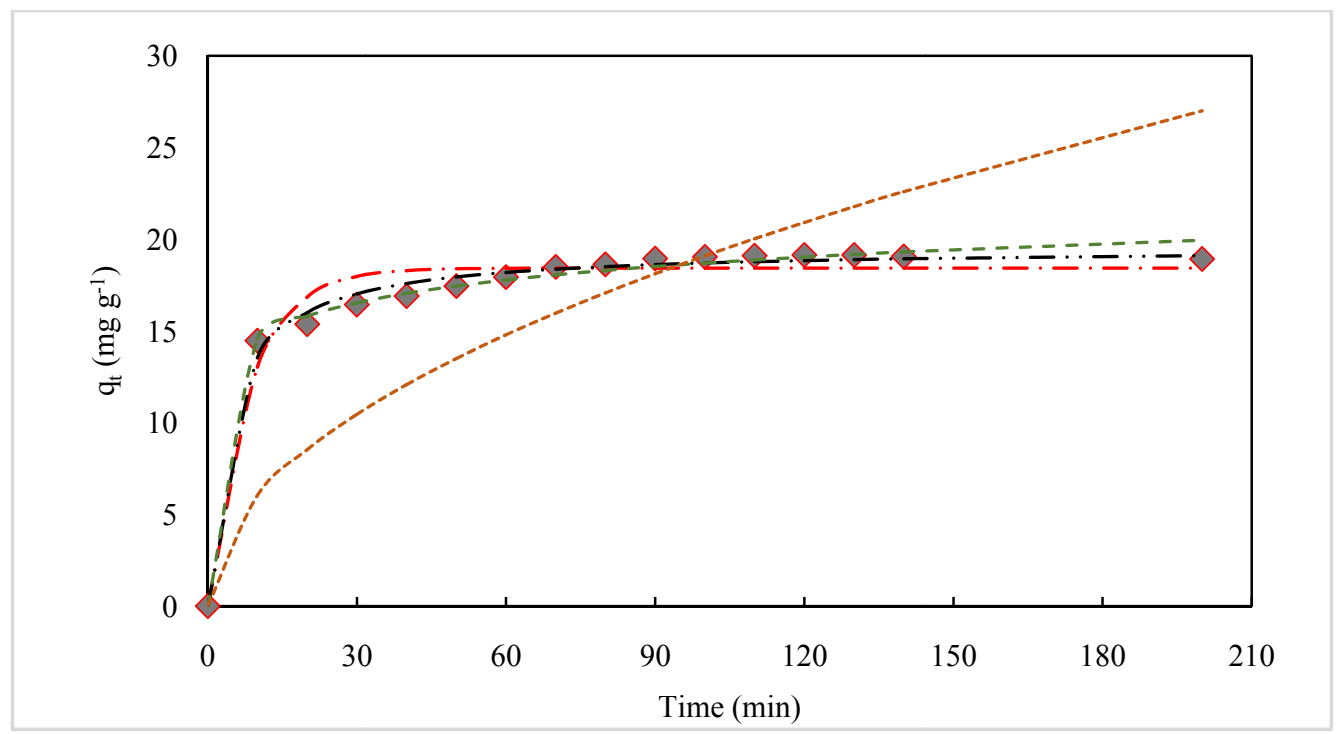

Fig. 6. Adjustment of experimental kinetic data to kinetic models for $\mathrm{Pb}$ (II) adsorption using $\mathrm{H}_{3} \mathrm{PO}_{4}$ impregnated activated carbons. $(\diamond)$ Experimental, $(-\cdots \rightarrow$, Pseudo-first order, (_- - Pseudo-second order, (- - - Elovich, (-----); Intraparticular Diffusion. 
The first-order model is based on the fact that each metal ion is assigned an adsorption site of the adsorbent material and corresponds to Equation 7 where the adsorption capacity in equilibrium $\left(\mathrm{mmolg}^{-1}\right)$ and $\mathrm{k}_{1}$ is the velocity constant of pseudo first order $\left(\mathrm{min}^{-1}\right)$ :

$q_{t}=q_{e}\left(1-e^{--k_{1} t}\right)$

The pseudo-second order model assumes that adsorbate is adsorbed at two active biomass sites and is represented by Eq. 8 where $\mathrm{k} 2$ is the second order adsorption constant $\left(\mathrm{g}^{-1} \mathrm{~min}^{-1}\right)$.

$q_{t}=\frac{t}{\left(\frac{1}{k_{2} q_{2}^{2}}\right)+\frac{t}{q_{e}}}$

The intraparticular diffusion model is based on the fact that within the pores of the adsorbent particle it is based on the transport of solute through the internal structure of the adsorbent pores and the diffusion itself in the solid, which leads to the adsorbent having a homogeneous porous structure[35], and is represented by Equation 10 where $k$ is the diffusion kinetic constant:

$$
q_{t}=\frac{1}{\beta} \operatorname{In}(\alpha \cdot \beta)+\frac{1}{\beta} \operatorname{In} t
$$

The intraparticular diffusion model is based on the fact that within the pores of the adsorbent particle it is based on the transport of solute through the internal structure of the adsorbent pores and the diffusion itself in the solid, which leads to the adsorbent having a homogeneous porous structure [36], and is represented by Equation 10 where $k$ is the diffusion kinetic constant:

$q_{t}=k \sqrt{t}$

The parameter values of the above-mentioned kinetic models and their sum of errors are shown in Table 6 and the graph in Fig. 6.

Table 6. Adjustment parameters of the kinetic adsorption models

\begin{tabular}{ccc}
\hline Kinetic model & Parameters & Value \\
\hline Pseudo-first order & $\mathrm{K}_{1}\left(\mathrm{~min}^{-1}\right)$ & 18.43 \\
\cline { 2 - 3 } & $\mathrm{q}_{\mathrm{e}}\left(\mathrm{mg} \mathrm{g}^{-1}\right)$ & 0.12 \\
\cline { 2 - 3 } & $\mathrm{Suma}^{1}$ & 12,45 \\
\hline Pseudo-second order & $\mathrm{K}_{2}$ & 0.011 \\
\cline { 2 - 3 } & $\mathrm{q}_{\mathrm{e}}\left(\mathrm{mg} \mathrm{g}^{-1}\right)$ & 19.53 \\
\cline { 2 - 3 } & $\mathrm{Suma}$ & 2.94 \\
\hline Elovich & $\mathrm{B}$ & 0.55 \\
\cline { 2 - 3 } & $\alpha$ & 576.02 \\
\cline { 2 - 3 } & $\mathrm{R}^{2}$ & 2.05 \\
\hline Intraparticulardifussion & $\mathrm{K}_{3}$ & 1.91 \\
\cline { 2 - 3 } & $\mathrm{R}^{2}$ & 300.44 \\
\hline
\end{tabular}

Where it is established that both the pseudo-second order model and Elovich adequately describe the experimental data. From the constant $\mathrm{k}_{2}$ it is shown that the initial adsorption rate is low, however, an important adsorption efficiency is achieved. According to the Elovich model, a high initial adsorption velocity? is also established, as well as more surface area for metal intake [7].

\section{Adsorption equilibrium}

The experimental adsorption data of $\mathrm{Pb}$ (II) were adjusted by the isothermal models of Langmuir and Freundlich. Five aqueous solutions at concentrations of $20 \mathrm{mg} \mathrm{L}^{-1}, 16 \mathrm{mg} \mathrm{L}^{-1}, 12 \mathrm{mg} \mathrm{L}^{-1}, 8 \mathrm{mg} \mathrm{L}^{-1}$ and $4 \mathrm{mg} \mathrm{L}^{-1}$ of $\mathrm{Pb}$ (II) with $20 \mathrm{~g}$ of adsorbent were used for this, as shown in Table 7.

Table 7. Initial and final concentration of $\mathrm{Pb}$ (II) for the construction of bioadsorption isotherms

\begin{tabular}{cccc}
\hline Sample code & $\left.\mathbf{C}_{\mathbf{0}} \mathbf{P b}(\mathbf{I I}) \mathbf{m g ~ L}^{\mathbf{- 1}}\right)$ & $\mathbf{C}_{\mathbf{e}} \mathbf{P b}(\mathbf{I I})(\mathbf{m g} / \mathbf{L})$ & $\mathbf{q}_{\mathbf{e}}\left(\mathbf{m g ~ g}^{\mathbf{- 1}}\right)$ \\
\hline 1 & 4 & 0.0456 & 0.0098 \\
\hline 2 & 8 & 0.1565 & 0.01961 \\
\hline 3 & 12 & 0.549 & 0.02863 \\
\hline 4 & 16 & 0.821 & 0.03795 \\
\hline 5 & 20 & 1.123 & 0.04719 \\
\hline
\end{tabular}


Langmuir's model considers that the adsorption energy of each molecule is independent of the surface of the material, occurring at specific locations of the adsorbent and without any interaction between molecules because the adsorption heat is constant for these sites; this model can be represented by the linear Equation 11, whereq $_{\max }\left(\mathrm{mg} \mathrm{g}^{-1}\right)$ is the maximum adsorption capacity y b $\left(\mathrm{L} \mathrm{mg}^{-1}\right)$ is Langmuir constant related to adsorption heat:

$\frac{C_{e}}{q_{e}}=\frac{C_{e}}{q_{e, \max }}+\frac{1}{q_{e, \max } * K_{L}}$

The Freundlich isothermal model makes use of Equation 12 and relates the concentration of a solution on the surface of an adsorbent to the concentration of the solution in the liquid with which it is in contact, assuming multiple adsorption layers with a non-uniform distribution of heat and adsorption affinities on the heterogeneous surface and can be applied for low and intermediate concentrations:

$\log \left(q_{e}\right)=\log K_{f}+\frac{1}{n} * \log \left(C_{e}\right) \log \left(q_{e}\right)$

Where, $K_{f}$ and $n$ are the Freundlich velocity constants designated as adsorption capacity and adsorption intensity, respectively. The value of $n$ lies in the range 1 to 10 , and is a reference point for evaluating adsorbentadsorbate interaction; the magnitude of the exponent, $n^{-1}$ determines the favorability of adsorption, since when $\mathrm{n}>1$ represents a favorable adsorption condition and this empirical constant indicates the adsorption intensity (L $\mathrm{mg}^{-1}$ ) and depends on the temperature and properties of the adsorbate and adsorbent.Ce is the residual concentration of solute in solution $\left(\mathrm{mg} \mathrm{L}^{-1}\right)$, which is the amount of adsorbate adsorbed by a unit mass of adsorbent in equilibrium $\left(\mathrm{mg} \mathrm{g}^{-1}\right)$. The adjustment of experimental data with the Langmuir and Freundlich models is shown in Table 8.

Table 8. Adjustment parameters to the isotherms of Langmuir and Freundlich.

\begin{tabular}{|c|c|c|}
\hline Model & Parameter & Value \\
\hline \multirow{3}{*}{ Langmuir } & $\left.\mathrm{Q}_{\max }\left(\mathrm{mg} \mathrm{g}^{-1}\right)\right)$ & 0.05457 \\
\cline { 2 - 3 } & $\mathrm{K}_{\mathrm{L}}$ & 3.2923 \\
\cline { 2 - 3 } & $\mathrm{R}^{2}$ & 0.9237 \\
\hline \multirow{4}{*}{ Freundlich } & $\mathrm{K}_{\mathrm{F}}$ & 0.04373 \\
\cline { 2 - 3 } & $\mathrm{n}^{-1}$ & 0.4745 \\
\cline { 2 - 3 } & $\mathrm{n}$ & 2.10748 \\
\cline { 2 - 3 } & $\mathrm{R}^{2}$ & 0.9734 \\
\hline
\end{tabular}

From the calculated parameters it can be observed that the value of $\mathrm{n}^{-1}=0.4233<1$, proving that bioadsorption is favorable. The parameter values of the mathematical equations and the correlations of the isotherms of Langmuir and Freundlich show values very close to 1, but the mathematical model of Freundlich is the one that best adjusts the adsorption of the $\mathrm{Pb}$ (II).It can then be indicated that the bioadsorption process was carried out in energetically heterogeneous active centers, forming multilayers on the entire surface. Considering the high values of $\mathrm{R}^{2}$, it can be said that adsorbed molecules can interact with each other by distribution and close distance between the active binding sites. These results are consistent with those reported by other sourcesAbbas et al.[29], Babarinde and Onyiaocha[11], Guoet al.[16], Tejada-Tovar et al.[8], Tejada-Tovar et al. [37].

\section{IV.CONCLUSION}

Orange peel (Citrus sinensis) is a good precursor for the preparation of activated carbon (AC), due to its low ash content $(0.398 \%)$, high volatile content $(83.15 \%)$ and fixed carbon content $(10.832 \%)$. The physicochemical characteristics of activated carbon such as BET analysis, determined that the area was $1626.44 \mathrm{~m}^{2} \mathrm{~g}^{-1} \mathrm{CA}, \mathrm{SEM}$ micro-photographs show porosityand Fourier FTIR transform infrared spectroscopy identified the different functional groups that may interfere with the adsorption of $\mathrm{Pb}$ (II) such as alcohols, organic acids, aldehydes and ketones.The activated carbon obtained from the orange peel has a positive effect, the greater the weight of the adsorbent, the greater the bioadsorption capacity of $\mathrm{Pb}$ (II) with $20 \mathrm{mg}$ of $\mathrm{CA}$, the bioadsorption capacity was $95.686 \%$.In addition, the mathematical model that best correlated the Freundlich equation with an $\mathrm{R}^{2}=0.97$, characterizing the $\mathrm{Pb}$ (II) bioadsorption process as a multi-layer process.

\section{REFERENCES}

[1] A. Ndé-Tchoupé, R. Crane, H. Mwakabona, C. Noubactep, and K. Njau, "Technologies for Decentralized Fluoride Removal: Testing Metallic Iron-based Filters," Water, vol. 7, no. 12, pp. 6750-6774, Nov. 2015.

[2] A. B. Pandit and J. K. Kumar, "Clean Water for Developing Countries," Annu. Rev. Chem. Biomol. Eng., vol. 6, no. 1, pp. 217-246, 2015.

[3] S. Chowdhury, M. A. J. Mazumder, O. Al-Attas, and T. Husain, "Heavy metals in drinking water: Occurrences, implications, and future needs in developing countries," Sci. Total Environ., vol. 569-570, pp. 476-488, Nov. 2016. 
[4] Sociedad Nacional de Minería Petróleo y Energía, "Boletín informativo," 2015. [Online]. Available: www.bnamericas.com/.../ministerio-de-energia-y-minas-republica-del-peru-mem-peru.

[5] S. N. Veliz, Contaminación e Intoxicación con metales pesados. Madrid, España: Reverte, 2010.

[6] C. Huancayo, El mantaro revive. Lima, Perú, 2007.

[7] C. Tejada Tovar, A. Villabona Ortiz, and E. Ruiz Paternina, "Remoción de Pb (II), Ni (II) y Cr (VI) en soluciones acuosas usando matrices modificadas químicamente," Prospectiva, vol. 12, no. 2, p. 7, Nov. 2014.

[8] C. T. Tovar and A. Herrera, "Remoción de plomo por biomasas residuales de cáscara de naranja (Citrus sinensis) y zuro de maíz (Zea mays),” Rev. U.D.C.A Actual. Divulg. Científica, vol. 19, no. 1, pp. 169-178, 2016.

[9] Munawar Iqbal and Rasheed A. Khera, "Adsorption of copper and lead in single and binary metal system onto Fumaria indica biomass," Chem. Int., vol. 1, no. 3, p. 157b-163b, 2015.

[10] R. J. E. Martins, V. J. P. Vilar, and R. A. R. Boaventura, "Kinetic modelling of cadmium and lead removal by aquatic mosses," Brazilian J. Chem. Eng., vol. 31, no. 1, pp. 229-242, Mar. 2014.

[11] A. Babarinde and G. Onyiaocha, "Equilibrium sorption of divalent metal ions onto groundnut (Arachis hypogaea) shell: kinetics, isotherm and thermodynamics," Chem. Int., vol. 2, no. 1, pp. 37-46, 2016.

[12] A. Safinejad, M. A. Chamjangali, N. Goudarzi, and G. Bagherian, "Synthesis and characterization of a new magnetic bio-adsorbent using walnut shell powder and its application in ultrasonic assisted removal of lead," J. Environ. Chem. Eng., vol. 5, no. 2, pp. 14291437, Apr. 2017.

[13] Y. Zhou, L. Zhang, and Z. Cheng, "Removal of organic pollutants from aqueous solution using agricultural wastes: A review," J. Mol. Liq., vol. 212, pp. 739-762, Dec. 2015.

[14] I. A. Aguayo-Villarreal, A. Bonilla-Petriciolet, and R. Muñiz-Valencia, "Preparation of activated carbons from pecan nutshell and their application in the antagonistic adsorption of heavy metal ions," J. Mol. Liq., vol. 230, pp. 686-695, Mar. 2017.

[15] Ç. Kırbıyık, A. E. Pütün, and E. Pütün, "Equilibrium, kinetic, and thermodynamic studies of the adsorption of Fe(III) metal ions and 2,4-dichlorophenoxyacetic acid onto biomass-based activated carbon by $\mathrm{ZnCl} 2$ activation," Surfaces and Interfaces, vol. 8, pp. 182192, Sep. 2017.

[16] Z. Guo, J. Zhang, H. Liu, and Y. Kang, "Development of a nitrogen-functionalized carbon adsorbent derived from biomass waste by diammonium hydrogen phosphate activation for Cr(VI) removal," Powder Technol., vol. 318, pp. 459-464, Aug. 2017.

[17] H. T. Kahraman and E. Pehlivan, "Cr 6+ removal using oleaster ( Elaeagnus ) seed and cherry (Prunus avium ) stone biochar," Powder Technol., vol. 306, pp. 61-67, Jan. 2017.

[18] R. R. Karri, N. S. Jayakumar, and J. N. Sahu, "Modelling of fluidised-bed reactor by differential evolution optimization for phenol removal using coconut shells based activated carbon,” J. Mol. Liq., vol. 231, pp. 249-262, Apr. 2017.

[19] F. Colpas, arnulfo a Taron, and W. Fong, "Analisis Del Desarrollo Textural De Carbones Activados Preparados a Partir De Zuro De Maíz,” Temas Agrar., vol. Vol. 20, no. 1, pp. 105-114, 2015.

[20] F. G. Borghi, "Estudo de viabilidade de aplicacao da casca de banana como biossorvente em tratamiento de efluentes residuais," UNIVERSIDADE DE SÃO PAULO, 2014.

[21] R. H. Hesas, A. Arami-Niya, W. M. A. Wan Daud, and J. N. Sahu, "Preparation and characterization of activated carbon from apple waste by microwave-assisted phosphoric acid activation: Application in methylene blue adsorption," BioResources, vol. 8, no. 2, pp. 2950-2966, 2013.

[22] G. Z. Kyzas, E. A. Deliyanni, and K. A. Matis, "Activated carbons produced by pyrolysis of waste potato peels: Cobalt ions removal by adsorption,” Colloids Surfaces A Physicochem. Eng. Asp., vol. 490, pp. 74-83, Feb. 2016.

[23] T. Khadiran, M. Z. Hussein, Z. Zainal, and R. Rusli, "Textural and Chemical Properties of Activated Carbon Prepared from Tropical Peat Soil by Chemical Activation Method,” BioResources, vol. 10, no. 1, pp. 986-1007, 2014.

[24] A. Nayak, B. Bhushan, V. Gupta, and P. Sharma, "Chemically activated carbon from lignocellulosic wastes for heavy metal wastewater remediation: Effect of activation conditions,” J. Colloid Interface Sci., vol. 493, pp. 228-240, May 2017.

[25] R. Hoseinzadeh Hesas, A. Arami-Niya, W. M. A. Wan Daud, and J. N. Sahu, "Comparison of oil palm shell-based activated carbons produced by microwave and conventional heating methods using zinc chloride activation,” J. Anal. Appl. Pyrolysis, vol. 104, pp. 176184, Nov. 2013.

[26] S. A. Aljlil and F. D. Alsewailem, “Adsorption of $\mathrm{Cu} \& \mathrm{Ni}$ on Bentonite Clay from Waste Water," Athens J. Nat. Form. Sci., vol. 1, no. March, pp. 21-30, 2014.

[27] F.-K. E, V. D. B. C, and W. F., "Physico-Chemical Activation of South African Bentonite Clay and Impact on Metal Adsorption Capacity," in 6th Int'l Conf. on Green Technology, Renewable Energy \& Environmental Engg. (ICGTREEE’2014), 2014, pp. 143148.

[28] G. Z. Kyzas and E. A. Deliyanni, "Modified activated carbons from potato peels as green environmental-friendly adsorbents for the treatment of pharmaceutical effluents," Chem. Eng. Res. Des., vol. 97, pp. 135-144, May 2015.

[29] M. Abbas, S. Kaddour, and M. Trari, "Kinetic and equilibrium studies of cobalt adsorption on apricot stone activated carbon," J. Ind. Eng. Chem., vol. 20, no. 3, pp. 745-751, May 2014.

[30] G. Delgadillo, "Caracterización de carbones activados a partir de pepas de níspero de palo (Mespilus communi) y su aplicación como material adsorbente de fenol," Pontificia Universidad Católica del Perú, 2011.

[31] L. Garcés and S. Coavas, "Evaluación de la capacidad de adsorción en la cáscara de naranja (citrus sinensis) modificada con quitosano para la remoción de $\mathrm{Cr}$ (VI) en aguas residuales," Universidad de Cartagena, 2012.

[32] D. A. Paredes, "Estudio de la adsorción de compuestos aromáticos mediante el carbon activado preparado a partir de la cáscara de Castaña.," Pontificia Universidad Catolica del Perú, 2011.

[33] C. Lavado Mezaa, M. del R. Koua, and S. Bendezu, "Revista de la Sociedad Química del Perú,” Rev. la Soc. Química del Perú, vol. 76, no. 2 , pp. $165-178,2010$.

[34] M. del R. Sun-Kou, D. Obregón-Valencia, Á. Pinedo-Flores, A. L. Paredes-Doig, and J. Aylas-Orejón, “Adsorción de metales pesados empleando carbones activados preparados a partir de semillas de aguaje," Rev. la Soc. Química del Perú, vol. 80, no. 4, pp. 225-236, 2014.

[35] R. Nadeem, Q. Manzoor, M. Iqbal, and J. Nisar, "Biosorption of Pb(II) onto immobilized and native Mangifera indica waste biomass," J. Ind. Eng. Chem., vol. 35, pp. 185-194, Mar. 2016.

[36] S. Yadav, V. Srivastava, S. Banerjee, C.-H. Weng, and Y. C. Sharma, "Adsorption characteristics of modified sand for the removal of hexavalent chromium ions from aqueous solutions: Kinetic, thermodynamic and equilibrium studies," CATENA, vol. 100, no. 1, pp. 120-127, Jan. 2013.

[37] C. Tejada, Á. Villabona Ortiz, and M. Jiménez Villadiego, "Remoción de Cromo Hexavalente sobre residuos de cacao pretratados químicamente,” Rev. U.D.C.A Actual. Divulg. Científica, vol. 20, no. 1, pp. 139-147, 2017. 